\title{
Detection of proteins on membranes and in microchannels using copper staining combined with scanning electrochemical microscopy
}

\author{
Maurizio Carano ${ }^{1}$, Niels Lion, Hubert H. Girault * \\ Laboratoire d'Electrochimie Physique et Analytique (LEPA), Institut des Sciences et Ingénierie Chimiques (ISIC), EPFL-SB-ISIC-LEPA, Station 6, \\ Ecole Polytechnique Fédérale de Lausanne (EPFL), CH-1015 Lausanne, Switzerland
}

Received 15 February 2006; received in revised form 20 June 2006; accepted 26 June 2006 Available online 4 August 2006

\begin{abstract}
Scanning electrochemical microscopy (SECM) and copper staining are combined to achieve visualisation of proteins on surfaces. Proteins are adsorbed on a polyvinylidene fluoride (PVDF) membrane or on a polyethylene terephthalate (PET) surface and stained using a standard protocol involving copper salts. Salts are then reduced to copper and detected by SECM with ferrocene methanol as a redox mediator in aqueous solution. During the SECM scan, the potential is held at a value at which the oxidation of the redox mediator occurs and a positive feedback current is detected when scanning over copper clusters. A negative feedback is observed elsewhere. This method enables unspecific protein adsorption mapping on polymeric membranes and into microchannels without any requirement of enzymatic activity or affinity to a labelled secondary reporter.
\end{abstract}

(c) 2006 Elsevier B.V. All rights reserved.

Keywords: Protein detection; Scanning electrochemical microscopy; SECM; Copper staining; Polyvinylidene fluoride; PVDF; Membrane

\section{Introduction}

The scanning electrochemical microscope (SECM) is related to the familiar scanning tunnelling and atomic force microscopes [1]. It allows observation and manipulation of spatially resolved electrochemical microenvironments. Therefore, this type of microscope can be used to perform surface characterisation and modification with high flexibility. The use of SECM in bioanalytics has been widely explored for various purposes, such as detection of biochemical events on surfaces, deposition or patterning of biomolecules, or imaging of living systems. SECM has been used for detection purposes mainly for the direct electrochemical imaging of DNA on inert surfaces without any derivatisation [2-4], or for the imaging of DNA chips in the positive feedback mode, where immobilised DNA

\footnotetext{
* Corresponding author. Tel.: +4121693 3151; fax: +41216933667.

E-mail address: hubert.girault@epfl.ch (H.H. Girault).

${ }^{1}$ Permanent address: Via Agricola 31, 86063 Carovilli, IS, Italy.
}

probes are used to capture DNA targets. For example, Wang et al. used target DNA prederivatised with biotin for further attachment of gold-derivatised streptavidin onto which silver is electrochemically grown; the SECM tip is then used to dissolve silver spots, $\mathrm{Ru}_{(}\left(\mathrm{NH}_{3}\right)_{6}^{2+}$ / $\mathrm{Ru}\left(\mathrm{NH}_{3}\right)_{6}^{3+}$ acting as a redox mediator between the protein spot and the SECM tip [5]. Alternatively, target DNA can be directly functionalised with electrochemically active moieties, such as ferrocenyl groups [6], or DNA hybridation can be detected thanks to electrochemically active DNA intercalators [6,7]. On the opposite, protein spot imaging has been relatively limited to enzymes that involve electron transfer for substrate catalysis, such as peroxidases or oxidases [8-16] or sandwich assays that involve enzymelabelled antibodies [17].

Complementarily, the SECM can be used to manipulate or pattern biomolecules on surfaces: for example, Wittstock and Wilhelm used the UME of the SECM to locally dissolve the self-assembled alkanethiolate layer over a gold surface; if the alkanethiolate decomposition is performed in 
the presence of $\omega$-functionalised thiol/disulfides, the dissolved monolayer is instantly replaced by a functionalised anchor layer that allow further immobilisation of biomolecules [18]. Alternatively, the SECM tip can be used to locally electropolymerise immobilisation surfaces, for example through the polypyrrole chemistry $[19,20]$.

Lastly, SECM has been used recently to image and analyse living cells, through the measurement of oxygen gradients in their close vicinity [21-28], neurotransmitter concentration released by exocytosis [29], NO release by endothelial cells [30-32], metabolised drugs and toxicants $[33,34]$; SECM can also be used to locate particular enzymatic activities [35,36], or measure global redox activity through the assessment of hydrophobic mediators regeneration by living cells [37-42].

We have recently introduced a new approach for the unspecific detection of proteins on two-dimensional or pseudo-two-dimensional surfaces, such as polymeric membranes; the main feature of the approach is that it does not rely on any particular enzymatic activity or affinity to a secondary reporter molecule: it is based on classical staining protocols used in protein gel electrophoresis. Protein spots are first exposed to a solution containing silver nanoparticles [43] or $\mathrm{Cu}^{2+}$ ions that complex with proteins on the surface [44]. Excess nanoparticles or $\mathrm{Cu}^{2+}$ ions are then washed out. In the case of copper staining, complexed $\mathrm{Cu}^{2+}$ ions are chemically reduced to metallic copper. The SECM tip is then used to image protein spots in the positive feedback mode by electrodissolution of proteincomplexed metals thanks to the use of properly chosen mediators. We show below that copper staining can be used in combination with SECM to image millimeter-sized protein spots on polyvinylidene fluoride (PVDF) membranes and micron-sized protein features in microchannels.

\section{Experimental}

\subsection{Chemicals and materials}

All chemicals were used as received. Ferrocene methanol and $\mathrm{KNO}_{3}$ were purchased from Aldrich and water was purified using a model Milli-Q plus 185 from Millipore (conductivity of $18.2 \mu \mathrm{S} \mathrm{cm}^{-1}$ ). Bovine serum albumin (BSA, 66,400 Da, $\mathrm{p} I \sim 4.5$ ) was purchased from Sigma (minimum purity 98\%). PVDF membranes (Immun-Blot ${ }^{\mathrm{TM}}$, for protein blotting, $0.2 \mu \mathrm{m}$ pore size) were purchased from Bio-Rad and cut into circles to fit the electrochemical cell. Alumina 0.3 and $0.05 \mu \mathrm{m}$ from Buehler, was used to polish all the metal electrodes and Mastertex polishing cloths from Buehler were employed for the SECM disk tip (working electrode).

\subsection{Microchannel fabrication}

The fabrication of microchip has been previously described [45]. Briefly, the polyethylene terephthalate (PET) sheet is photoablated by a UV excimer laser (Argon
Fluor Excimer Laser at $193 \mathrm{~nm}$; Lambda Physik LPX 2051, Göttingen, Germany). In the present microdevice, the feeding microchannel has a trapezoidal cross section, due to the photoablation process, with an average width of $100 \mu \mathrm{m}$ and a depth of $40 \mu \mathrm{m}$.

\subsection{Sample preparation}

PVDF membranes were prepared as described previously $[43,44]$ : briefly, they were first wetted with methanol and copiously rinsed with water before sample deposition. PET disks with microchannel arrays were first spotted by the drop spot technique: $1 \mu \mathrm{L}$ of BSA in pure water at concentrations of $1.5 \mu \mathrm{M}, 15$ and $1.5 \mathrm{nM}$ were spotted over the channels corresponding to final amounts of $0.1 \mu \mathrm{g}, 1 \mathrm{ng}$, and $0.1 \mathrm{ng}$ of protein, respectively, and a spot surface of ca. $1 \mathrm{~mm}^{2}$. After evaporation of the solvent, a razor blade was used to remove the protein outside the channels.

\subsection{Copper staining procedure}

The procedure followed for the staining process was that introduced by Lee et al. [46]. A $0.3 \mathrm{M}$ copper chloride solution was prepared using purified water, added to the protein spots and allowed to react for about $30 \mathrm{~min}$ (formation of $\mathrm{Cu}^{2+}$-protein complex). After the sample was dried and washed with abundant water, a $0.3 \mathrm{M} \mathrm{NaBH}_{4}$ solution was added in order to reduce the copper $\mathrm{Cu}^{2+}$ to $\mathrm{Cu}^{0}$. After about $5 \mathrm{~min}$ the solution was removed and the sample was carefully rinsed with purified water. After checking the status of the samples under the light microscope, the PVDF membranes or PET disks were placed in the SECM cell. A water solution of ferrocenemethanol $(1 \mathrm{mM})$ and $\mathrm{KNO}_{3}(0.1 \mathrm{M})$ was used to perform the electrochemical experiments. Approach curves were obtained far from the spots and negative feedback was observed.

\subsection{Instrumentation}

CHI 900 SECM equipment was used for all the electrochemical measurements; a Leitz microscope, model Laborlux D and a 2 Megapixel Digital camera were used to capture pictures of the samples before the experiments. For the SECM measurements a custom-made electrochemical cell was employed (see Scheme 1). The cell was fabricated with the purpose to allow a firm and easy positioning of the PVDF membranes. The disk shaped samples were placed on top of the screw-like bottom of the cell. To prevent leaks from the bottom of the cell, an o-ring was placed between the sample and a ring channel indent in the cell. All measurements were performed using a three electrodes set-up: working electrode was a $25 \mu \mathrm{m}$ in diameter platinum disk SECM tip (purchased from $\mathrm{CHI}, \mathrm{RG}$ value was 5), reference electrode was an $\mathrm{Ag} / \mathrm{AgCl}$ or a silver wire coil (quasi-reference) and the counter electrode was a platinum wire. The microelectrode electrochemical behaviour was checked as previously described [47] to 


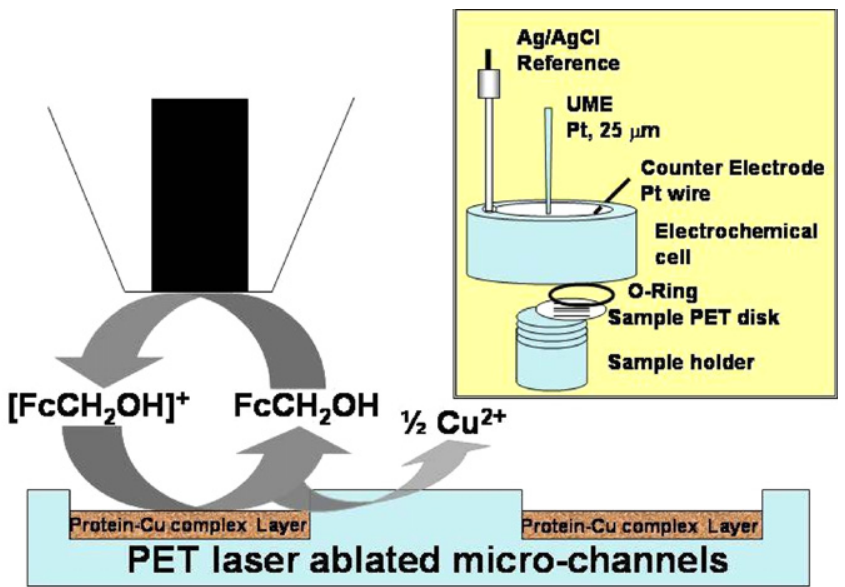

Scheme 1. Schematic representation of the electrochemical principle used to detect protein through copper dissolution in PET micro-channels. A view of the custom-made electrochemical cell is given in the up-right corner of the draw. Dimensions are not to scale.

make sure that the electrochemical response was the one expected. In particular cyclic voltammetry experiments were carried out along with negative and positive approach curves that were acquired and fitted to theory.

\section{Results and discussion}

In our previous studies, home-made silver nanoparticles were used to tag proteins immobilised on PVDF membranes, and home-synthesised osmium tris-bipyridine $\left(\mathrm{Os}(\mathrm{bpy})_{3}^{2+}\right)$ was used as a redox mediator to detect the dissolution of silver nanoparticles [43]. In this work, we explore the potential of more readily available compounds (namely copper salts and ferrocene methanol as a redox mediator) for the SECM detection of proteins immobilised on surfaces or polymeric membranes. Bovine serum albumin was used as a model compound. PVDF membranes bind peptides and proteins through hydrophobic interactions with a high binding capacity (140$150 \mu \mathrm{g} / \mathrm{cm}^{2}$ of frontal surface for BSA, supplier data [48]) while the interaction with PET leads to a lower binding capacity (around $200 \mathrm{ng} / \mathrm{cm}^{2}$ [49]). The relatively small spot size on membranes (ca. $1 \mathrm{~mm}^{2}$, corresponding to $1.5 \times 10^{-12}, 15 \times 10^{-14}$ and $1.5 \times 10^{-14} \mathrm{~mol} / \mathrm{mm}^{2}$ ) was chosen to be comparable to spot sizes usually encountered in gel electrophoresis and electroblotting assays (ca. $1-5 \mathrm{~mm}^{2}$ ). Scheme 1 shows the principle of the proposed approach to the detection of proteins. The $25 \mu \mathrm{m}$ working electrode is held at $+0.25 \mathrm{~V}$ vs. $\mathrm{Ag} / \mathrm{AgCl}$; at this value the oxidation of the redox mediator is observed. When the tip is close enough to the sample, the oxidised form of the mediator reacts with the complexed copper leading to the production of $\mathrm{Cu}^{2+}$. Ferrocene methanol was chosen as mediator because the standard redox potential for the couple ferrocene methano ${ }^{1+/ 0}(0.480 \mathrm{~V}$ vs. SCE [50]) is positive enough so that its oxidised form is able to accept electrons from $\mathrm{Cu}$ atoms attached to the protein on the substrate $\left(\mathrm{Cu}^{2+} / \mathrm{Cu}\right.$ standard potential is
$0.340 \mathrm{~V}$ vs. SCE [51]). Furthermore, this potential is not too close to the positive limit of the potential window in water. After proper characterisation of the tip used for the experiments, the electrochemical set up was tested by performing cyclic voltammograms (CVs) in a $1 \mathrm{mM}$ ferrocene methanol aqueous solution $(0.1 \mathrm{M}$ $\mathrm{KNO}_{3}$ as supporting electrolyte).

Approach curves to the PVDF substrate yielded a negative feedback due to the non-conductive nature of the surface and the absence of non-specific adsorption of copper on bare PVDF. Fig. 1 shows one of these approach curves (solid line) compared to the theoretical values (dotted line). Comparison of the experimental results with the theory revealed that it was possible to place the tip very close to the surface $(2-3 \mu \mathrm{m}$ or less). Nevertheless, the fit was not as good as during the characterisation of the tip. This could be due to the porosity of the substrate that allows a higher flux of redox species to the electrode up to a closer tip/substrate distance if compared to a non-porous material. In this sense, the experimental current is found above the one predicted by theory and it decreases more sharply than the latter at very close distances from the substrate. This means that the current level will be higher in our case at comparable distances. After approaching the membrane, the electrode was withdrawn of about $20 \mu \mathrm{m}$. Cyclic voltammetry curves were acquired both before and after the approach scans so as to check that the feedback regime was preserved. A cyclic voltammogram acquired at

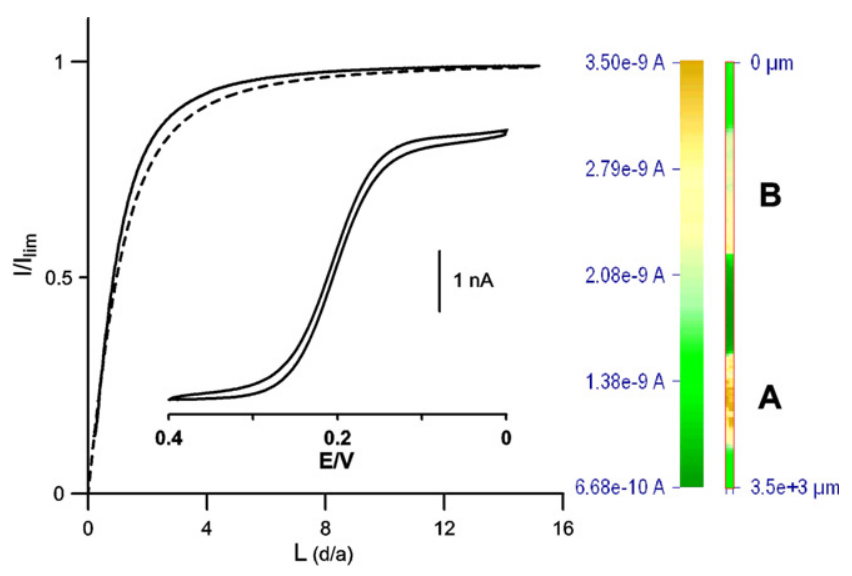

Fig. 1. (Left) Scanning approach curve acquired at $2 \mu \mathrm{m} / \mathrm{s}, 25 \mu \mathrm{m}$ platinum disk working electrode, $\mathrm{Ag}$ wire as quasi-reference electrode, $\mathrm{Pt}$ wire as counter electrode. Approach curve is presented in $L=d / a$ vs. normalized current $I=i / i_{\mathrm{T}, \propto}$ where $d$ is the travelling distance from the substrate (PVDF membrane), $a$ the tip radius, $i$ the recorded current and $i_{\mathrm{T}, \propto}$ the limiting current. Equilibration time before scan: $50 \mathrm{~s}$ at $0.35 \mathrm{~V}$ vs. $\mathrm{Ag}$ wire. $1 \mathrm{mM}$ ferrocenemethanol aqueous solution, $0.1 \mathrm{M} \mathrm{KNO}_{3}$ as supporting electrolyte. $T=25^{\circ} \mathrm{C}$. Dotted line is the simulated curve. Inset: cyclic voltammetry acquired in the same experimental conditions, away from the substrate at scan rate $v=0.05 \mathrm{~V} / \mathrm{s}$. (Right) SECM scan performed in the same experimental conditions with the tip at about $10 \mu \mathrm{m}$ distance from the substrate. Scan performed over two spots of protein $\left(10 \mathrm{ng} / \mathrm{mm}^{2}\right.$ and $1 \mathrm{ng} / \mathrm{mm}^{2}$, brown spots $\mathrm{A}$ and $\mathrm{B}$, respectively) stained with copper according to procedure reported in Section 2. Scanning speed was $300 \mu \mathrm{m} / \mathrm{s}$. (For interpretation of the references in color in this figure legend, the reader is referred to the web version of this article.) 
$50 \mathrm{mV} / \mathrm{s}$ is shown in Fig. 1; the tip was held away from the substrate (i.e. outside of the feedback regime area). The use of the custom made electrochemical cell resulted in a very good flatness of the samples (PVDF membrane or PET disk): a deviation in the range of $1-5 \mu \mathrm{m}$ over $1 \mathrm{~mm}$ scans within several experiments was measured by fitting approach curves to the theory at different locations.

After checking the overall detection system, protein spots were imaged: the right-hand side of Fig. 1 (narrow band image) shows a scan performed over two spots of protein at two different concentrations (10 and $1 \mathrm{ng} /$ $\mathrm{mm}^{2}$ ). The tip (held at a potential of $0.35 \mathrm{~V}$ vs. Ag wire) was about $10 \mu \mathrm{m}$ away from the substrate and travelled $3.5 \times 10^{3} \mu \mathrm{m}$ in the $Y$ direction and $50 \mu \mathrm{m}$ in the $X$ direction. The current for the two areas (in brown in the figure) is consistently and reproducibly different, and has been shown previously to allow the detection of protein spots down to $0.1 \mathrm{ng}$ of protein per spot [44]. Since the absolute values for the current also depend on the distance between the substrate and the tip, it is important to underline how some caution is necessary when trying to quantify an unknown sample.

The following part of the work was carried out on laserablated microchannels obtained on polyethylene terephthalate sheet disks in order to verify the possibility of detecting proteins within a well-confined area. Fig. 2 shows an SECM scan performed over three microchannels filled with a $0.15 \mu \mathrm{M}$ BSA solution (corresponding to approximately $10 \mathrm{ng}$ of protein deposited) after following the procedure explained in Section 2. The experiments were reproducible even over large scanned areas $(1 \mathrm{~mm} \times 1 \mathrm{~mm}$ and bigger). The level of current obtained over the channels is clearly dependent also on the distance of the tip but if the

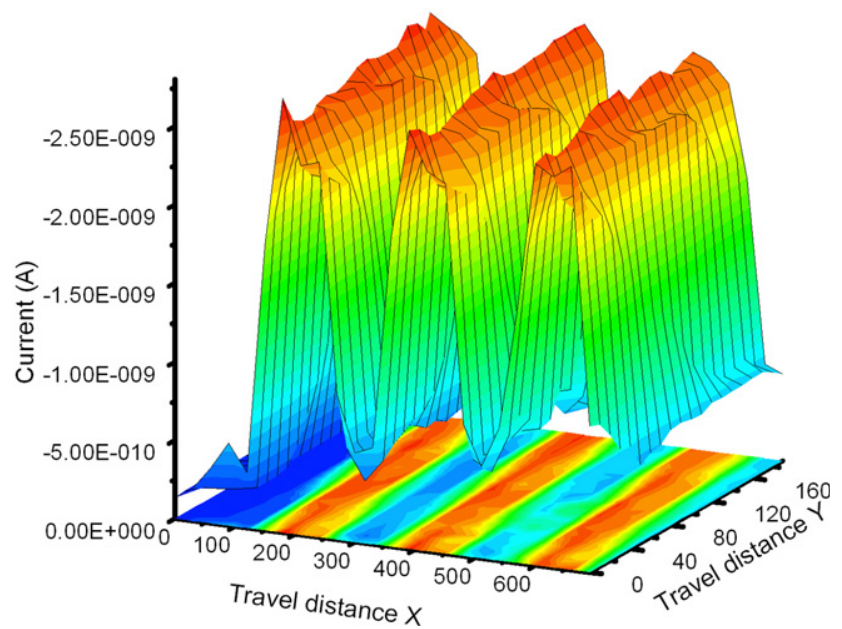

Fig. 2. SECM image of three microchannels filled with $10 \mathrm{ng} / \mathrm{mm}^{2}$ of BSA stained with copper following the procedure reported in Section 2. Scanning speed was $300 \mu \mathrm{m} / \mathrm{s}$, a $25 \mu \mathrm{m}$ platinum disk working electrode, $\mathrm{Ag}$ wire as quasi-reference electrode, $\mathrm{Pt}$ wire counter electrode were used. Equilibration time before scan: $50 \mathrm{~s}$ at $0.35 \mathrm{~V}$ vs. $\mathrm{Ag}$ wire. $1 \mathrm{mM}$ ferrocenemethanol aqueous solution, $0.1 \mathrm{M} \mathrm{KNO}_{3}$ as supporting electrolyte. $T=25^{\circ} \mathrm{C}$. sample is approached away from the microchannels, the real distance calculated from theory and the tip withdrawal of the same amount; a very good reproducibility of the measurements is found. The scan also shows that the method used to prepare the sample is able to confine the protein and the copper only within the microchannels: in fact no current due to copper dissolution is found outside the microchannels. Also the width of the channels found in the electrochemical experiment is extremely close to the real one.

Fig. 3 shows the SECM scan over a microchannel array in which a protein concentration gradient $\left(10-0.1 \mathrm{ng} / \mathrm{mm}^{2}\right)$ was realized. To do so a first drop of solution $(0.15 \mu \mathrm{M}$ BSA in water) was placed on area I (right-hand side of Fig. 3, zone A) and after the solvent dried out a second drop at a lower concentration (15 $\mathrm{nM})$ was placed on area II which partially overlaps with area I. After the second drop dried out a third drop $(1.5 \mathrm{nM})$ was placed on area III. The same procedure was followed for zone B. The area delimited by the black square in the scheme is the one scanned by SECM and depicted in the left-hand side of Fig. 3. In this experiment the instrument is able to detect the variations of concentration along the channels. Table 1 reports the values for the current measured at different concentrations of protein within the microchannels. The theoretical limit of detection is also reported and has been evaluated as the noise $+3 \times \sigma$ in two ways. The first value corresponds to the limit of detection where "noise" is the background signal level due to the oxidation of the mediator far from the spots, and $\sigma$ its standard deviation. The second limit of detection is obtained by taking the current over an empty microchannel as "noise". Remarkably, the same limit of detection was obtained for the different protein areas, due to the high reproducibility of the current

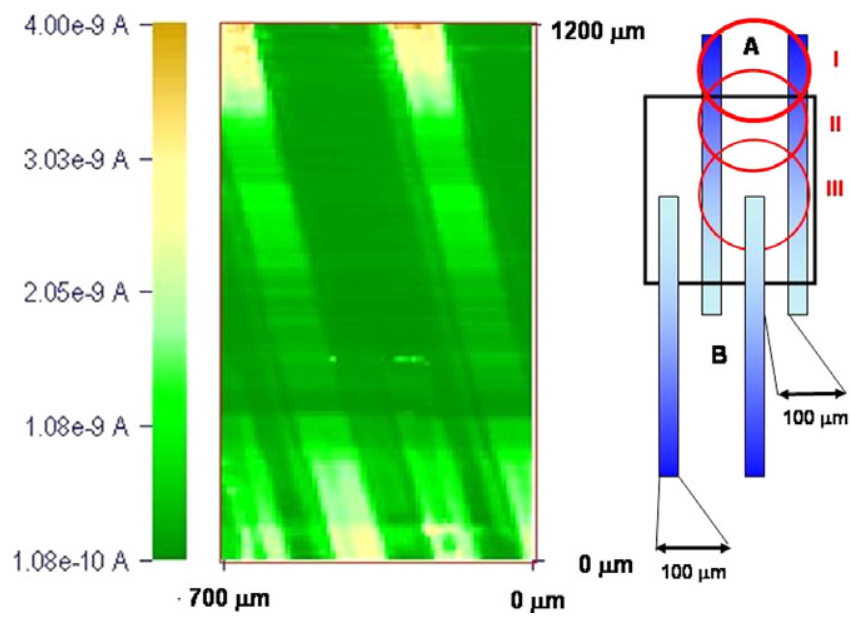

Fig. 3. SECM scan over an array of microchannels laser-ablated in a PET disk in which protein gradients were generated. A $25 \mu \mathrm{m}$ platinum disk working electrode, $\mathrm{Ag}$ wire as quasi-reference electrode, $\mathrm{Pt}$ wire counter electrode were used. Equilibration time before scan: $50 \mathrm{~s}$ at $0.35 \mathrm{~V}$ vs. $\mathrm{Ag}$ wire. $1 \mathrm{mM}$ ferrocenemethanol aqueous solution, $0.1 \mathrm{M} \mathrm{KNO}_{3}$ as supporting electrolyte. $T=25^{\circ} \mathrm{C}$. Preparation of the sample is reported in the text. 
Table 1

Peak current values for four different protein concentrations in the microchannels

\begin{tabular}{lll}
\hline $\begin{array}{l}\text { Microchannel } \\
\text { (protein amount)/ } \\
\mathrm{ng} / \mathrm{mm}^{2}\end{array}$ & $\begin{array}{l}\text { Average peak } \\
\text { current } / 10^{9} \mathrm{~A}\end{array}$ & $\begin{array}{l}\text { Theoretical limit } \\
\text { of detection } / 10^{10} \mathrm{~A}\end{array}$ \\
\hline 10 & -2.64 & $-4.51 /-9.8$ \\
1.0 & -2.15 & $-4.51 /-9.8$ \\
0.1 & -1.44 & $-4.51 /-9.8$ \\
0 & -0.34 & -4.51 \\
\hline
\end{tabular}

The first limit of detection is evaluated from the scan itself, far from the protein areas. The second limit of detection for the first three concentrations is calculated by considering the current over an empty channel as noise. Data were acquire at a scanning speed in $X$ direction: $300 \mu \mathrm{m} / \mathrm{s}$, $25 \mu \mathrm{m}$ platinum disk working electrode, silver wire as quasi-reference electrode, platinum wire as a counter electrode. Equilibration time before scan: $50 \mathrm{~s}$ at $0.35 \mathrm{~V}$ vs. $\mathrm{Ag} / \mathrm{AgCl} .1 \mathrm{mM}$ ferrocenemethanol aqueous solution, $0.1 \mathrm{M} \mathrm{KNO}_{3}$ as supporting electrolyte. $T=25^{\circ} \mathrm{C}$.

value far from the spots. The calculated theoretical limit of detection of $4.51 \times 10^{-10} \mathrm{~A}$ is roughly speaking three times lower then the average signal obtained over the protein spots at the lowest concentration probed. This means that $0.1 \mathrm{ng}$ over ca. $1 \mathrm{~mm}^{2}$ is still above the practical limit of detection of the system. Very interestingly, this limit of detection is below the range of classical staining techniques used in membrane blotting analysis (typically in the subnanogram range) [52].

These data demonstrate that the present approach has a good sensitivity over the concentration range explored and the noise level will allow pushing down of maybe 10 times the minimum amount of protein detected in this work. We have to realize that the background noise depend also on the distance of the tip from the substrate and being closer to the non-conductive surface of the PET sheets will also mean experiencing a lower current (i.e. a lower background noise). Fig. 4 shows four linear scans along the $X$ axis performed over sections of two microchannels containing variable amounts of protein. The concentration values were the same as in Table 1 and in Fig. 3 and we can clearly see that even performing a single line scan for each sample results in reliable data. This result is extremely important for the methodological implications of this approach to the detection of micron-size proteins spots on surfaces. Time wise each of the line scans requires just $2 \mathrm{~s}$ to be performed, and thus results on fast detection possibilities for surfaces of moderate areas, or when moderate spatial resolution is needed.

Whereas no true quantitation possibility can be claimed from the above-described results, it must be stated that absolute quantification is not the primary goal of this study, where emphasis is put on detectability. The important feature of protein spots detection systems in gel, electroblotted membrane or, eventually, microchannel analysis is not their ability to quantify proteins, but to detect low abundant proteins. The system presented above already reaches detection limits at least comparable to state-ofthe-art techniques such as Coomassie or silver staining. SECM as thus the potential to surpass any classical stain-

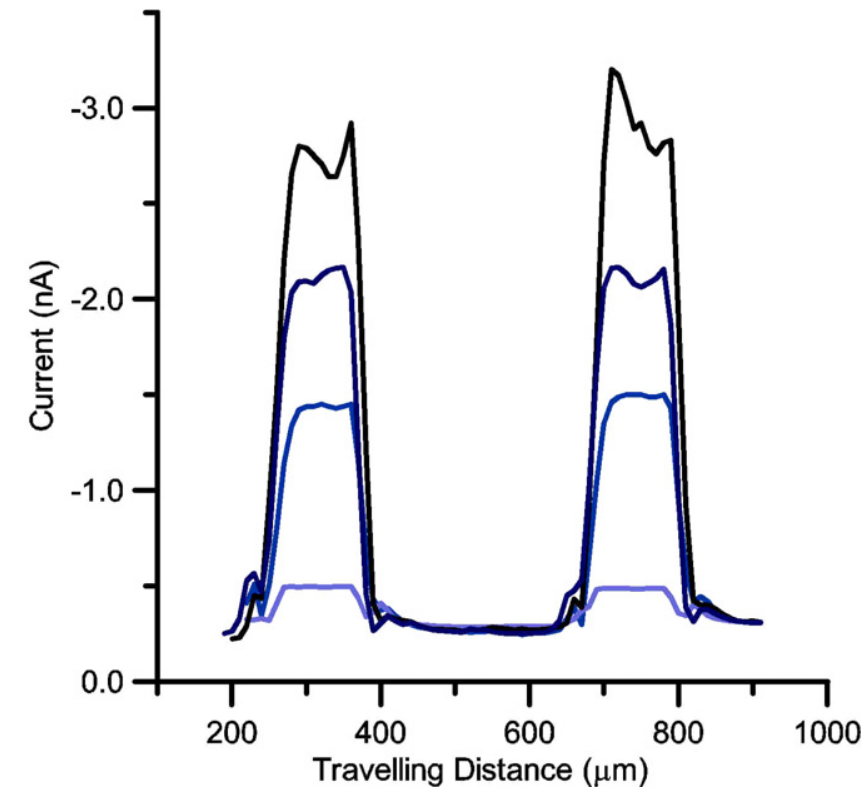

Fig. 4. Current profile over two microchannels over zones of different protein concentrations. Scans were taken in the $X$ direction at $300 \mu \mathrm{m} / \mathrm{s}$. The bottom scan is the scan over the two empty zones; higher current is observed, as expected, while scanning over the deeper area. The second, third and fourth (uppermost) line scans were taken over microchannels areas filled with spots of protein $170 \mathrm{nM}, 17 \mathrm{nM}$ and $1.7 \mathrm{nM}$ protein solution, corresponding to $10 \mathrm{ng} / \mathrm{mm}^{2}, 1 \mathrm{ng} / \mathrm{mm}^{2}$ and $0.1 \mathrm{ng} / \mathrm{mm}^{2}$. All conditions as in Fig. 1.

ing technique in terms of sensitivity for the detection of protein spots on membranes or flat surfaces. A possible development would be to show the ability to completely dissolve the deposited metal (whether by the SECM tip itself or more advantageously chemically) to make possible protein recovery and subsequent analysis, typically by mass spectrometry. Chemical protocols have already been developed for complete destaining of protein spots labelled with silver, copper and zinc, and destaining kits are commercially available from major life science suppliers (e.g. Biorad). The compatibility of such destaining protocols with further affinity assays [53] and mass spectrometric analysis of proteins [54] accounts for the ability to completely remove metals from the protein.

We used herein a fast scanning speed of $300 \mu \mathrm{m} / \mathrm{s}$ to ensure the compatibility of the system with relatively large surface (or long line) scanning, such as those encountered in gel electrophoresis followed by membrane electroblotting. However, scanning a $5 \times 5 \mathrm{~cm}$ area with a $100 \mu \mathrm{m}$ step between each scanning line would then require $23 \mathrm{~h}$. In this sense the possibility of using single line scans over arrays is an important feature of this technique. This approach would be compatible as a whole surface scanning system only with miniaturized separations or with multi-tips scanning instruments [55]. Alternatively, as already mentioned it can be envisioned as a technique complementary to classical stains to mine deeper in zones were protein spots are suspected but cannot be seen or to obtain fast scans along lanes of 1D gels. At the same time, this high speed we used, combined with a relatively large tip diameter of $25 \mu \mathrm{m}$, 
resulted in relatively low spatial resolution (pixel size is around $10 \mu \mathrm{m}$ in our scans). But SECM can also be pushed towards high resolution imaging: Bard et al. calculated that under optimised conditions (substrate-tip distance, tip diameter, etc.), detection of features 10-20 times smaller that the tip diameter should be feasible [50]. This would as well be useful in the detection of low abundant proteins on pseudo-two-dimensional surfaces.

\section{Conclusions}

A new approach to the detection of proteins on PET microchannels (but also on PVDF membranes) was presented: once adsorbed on the substrate surface, proteins are first stained with copper chloride, which is chemically reduced to copper metal. The surface is then scanned by the SECM tip, with ferrocenemethanol acting as an electrochemical mediator to detect copper dissolution in the positive feedback mode. The initial experimental results presented herein show that in this scheme, SECM can detect amounts of proteins as low as $0.1 \mathrm{ng}$ (over an area of ca. $1 \mathrm{~mm}^{2}$ ) in microchannels. These results are already comparable to state-of-the-art staining techniques. To our knowledge, this strategy is the first one that allows unspecific detection of proteins by scanning electrochemical microscopy, i.e. not based on particular enzymatic activity or affinity to a secondary detection antibody used in sandwich or Western blot assays.

\section{Acknowledgement}

Authors are part of the TMR network SUSANA (Supramolecular Self-Assembly of Interfacial Nanostructures).

\section{References}

[1] A.J. Bard, M.V. Mirkin, Scanning Electrochemical Microscopy, Marcel Dekker, New York, 2001.

[2] F.R.F. Fan, A.J. Bard, Proc. Natl. Acad. Sci. USA 96 (1999) 1422214227.

[3] J. Wang, F.M. Zhou, J. Electroanal. Chem. 537 (2002) 95-102.

[4] F. Turcu, A. Schulte, G. Hartwich, W. Schuhmann, Biosens. Bioelectron. 20 (2004) 925-932.

[5] J. Wang, F.Y. Song, F.M. Zhou, Langmuir 18 (2002) 6653-6658.

[6] S. Takenaka, Bull. Chem. Soc. Jpn. 74 (2001) 217-224.

[7] K. Yamashita, M. Takagi, K. Uchida, H. Kondo, S. Takenaka, Analyst 126 (2001) 1210-1211.

[8] H.F. Zhou, S. Kasai, T. Yasukawa, T. Matsue, Electrochemistry 67 (1999) 1135-1137.

[9] H.F. Zhou, S. Kasai, T. Matsue, Anal. Biochem. 290 (2001) 8388.

[10] J.F. Zhou, C. Campbell, A. Heller, A.J. Bard, Anal. Chem. 74 (2002) 4007-4010.

[11] C. Kranz, G. Wittstock, H. Wohlschlager, W. Schuhmann, Electrochim. Acta 42 (1997) 3105-3111.

[12] G. Wittstock, W. Schuhmann, Anal. Chem. 69 (1997) 5059-5066.

[13] T. Wilhelm, G. Wittstock, R. Szargan, Fresen. J. Anal. Chem. 365 (1999) 163-167.

[14] I. Turyan, T. Matsue, D. Mandler, Anal. Chem. 72 (2000) 3431-3435.

[15] M. Mosbach, H. Zimmermann, T. Laurell, J. Nilsson, E. Csoregi, W. Schuhmann, Biosens. Bioelectron. 16 (2001) 827-837.
[16] G. Wittstock, T. Wilhelm, S. Bahrs, P. Steinrucke, Electroanalysis 13 (2001) 669-675.

[17] S. Kasai, A. Yokota, H.F. Zhou, M. Nishizawa, K. Niwa, T. Onouchi, T. Matsue, Anal. Chem. 72 (2000) 5761-5765.

[18] G. Wittstock, T. Wilhelm, Anal. Sci. 18 (2002) 1199-1204.

[19] S. Szunerits, L. Bouffier, R. Calemczuk, B. Corso, M. Demeunynck, E. Descamps, Y. Defontaine, J.B. Fiche, E. Fortin, T. Livache, P. Mailley, A. Roget, E. Vieil, Electroanalysis 17 (2005) 2001-2017.

[20] E. Fortin, Y. Defontaine, P. Mailley, T. Livache, S. Szunerits, Electroanalysis 17 (2005) 495-503.

[21] T. Yasukawa, Y. Kondo, I. Uchida, T. Matsue, Chem. Lett. (1998) $767-768$.

[22] H. Skiku, T. Shiraishi, H. Ohya, T. Matsue, H. Abe, H. Hoshi, M. Kobayashi, Electrochemistry 68 (2000) 890-892.

[23] T. Yasukawa, T. Kaya, T. Matsue, Electroanalysis 12 (2000) 653-659.

[24] H. Shiku, T. Shiraishi, H. Ohya, T. Matsue, H. Abe, H. Hoshi, M. Kobayashi, Anal. Chem. 73 (2001) 3751-3758.

[25] T. Kaya, Y.S. Torisawa, D. Oyamatsu, M. Nishizawa, T. Matsue, Biosens. Bioelectron. 18 (2003) 1379-1383.

[26] Y. Takii, K. Takoh, M. Nishizawa, T. Matsue, Electrochim. Acta 48 (2003) 3381-3385.

[27] T. Kaya, D. Numai, K. Nagamine, S. Aoyagi, H. Shiku, T. Matsue, Analyst 129 (2004) 529-534.

[28] H. Shiku, T. Shiraishi, S. Aoyagi, Y. Utsumi, M. Matsudaira, H. Abe, H. Hoshi, S. Kasai, H. Ohya, T. Matsue, Anal. Chim. Acta 522 (2004) 51-58.

[29] L.P. Bauermann, W. Schuhmann, A. Schulte, Phys. Chem. Chem. Phys. 6 (2004) 4003-4008.

[30] J. Oni, N. Diab, I. Radtke, W. Schuhmann, Electrochim. Acta 48 (2003) 3349-3354.

[31] J. Oni, A. Pailleret, S. Isik, N. Diab, I. Radtke, A. Blochl, M. Jackson, F. Bedioui, W. Schuhmann, Anal. Bioanal. Chem. 378 (2004) 1594-1600.

[32] A. Pailleret, J. Oni, S. Reiter, S. Isik, M. Etienne, F. Bedioui, W. Schuhmann, Electrochem. Commun. 5 (2003) 847-852.

[33] J. Mauzeroll, A.J. Bard, O. Owhadian, T.J. Monks, Proc. Natl. Acad. Sci. USA 101 (2004) 17582-17587.

[34] J. Mauzeroll, A.J. Bard, Proc. Natl. Acad. Sci. USA 101 (2004) 7862 7867.

[35] H.F. Zhou, H. Shiku, S. Kasai, H. Noda, T. Matsue, H. OhyaNishiguchi, H. Kamada, Bioelectrochemistry 54 (2001) 151-156.

[36] H.F. Zhou, S. Kasai, H. Noda, H. Ohya-Nishiguchi, H. Shiku, T. Matsue, Bull. Chem. Soc. Jpn. 76 (2003) 1757-1762.

[37] B. Liu, S.A. Rotenberg, M.V. Mirkin, Proc. Natl. Acad. Sci. USA 97 (2000) 9855-9860.

[38] B. Liu, W. Cheng, S.A. Rotenberg, M.V. Mirkin, J. Electroanal Chem. 500 (2001) 590-597.

[39] C.X. Cai, B. Liu, M.V. Mirkin, H.A. Frank, J.F. Rusling, Anal. Chem. 74 (2002) 114-119.

[40] B. Liu, S.A. Rogenberg, M.V. Mirkin, Anal. Chem. 74 (2002) 6340-6348.

[41] W.J. Feng, S.A. Rotenberg, M.V. Mirkin, Anal. Chem. 75 (2003) 4148-4154.

[42] S.A. Rotenberg, M.V. Mirkin, J. Mammary Gland Biol. Neoplasia 9 (2004) 375-382.

[43] M. Carano, N. Lion, J.P. Abid, H.H. Girault, Electrochem. Commun. 6 (2004) 1217-1221.

[44] M. Carano, N. Lion, H.H. Girault, Chimia 59 (2005) 105-108.

[45] M.A. Roberts, J.S. Rossier, P. Bercier, H. Girault, Anal. Chem. 69 (1997) 2035-2042.

[46] C. Lee, A. Levin, D. Branton, Anal. Biochem. 166 (1987) 308-312.

[47] A.J. Bard, F.R. Fan, M.V. Mirkin, in: A.J. Bard, M.V. Mirkin (Eds.), Electroanalytical Chemistry, Marcel Dekker, New York, 1994, p. 243.

[48] Biorad, 2004. Available from: $<$ http://wwww.biorad.com $>$.

[49] J.S. Rossier, G. Gokulrangan, H.H. Girault, S. Svojanovsky, G.S Wilson, Langmuir 16 (2000) 8489-8494. 
[50] A.J. Bard, M.V. Mirkin, P.R. Unwin, D.O. Wipf, J. Phys. Chem. 96 (1992) 1861-1868.

[51] D. Mandler, A.J. Bard, J. Electrochem. Soc. 136 (1989) 3143.

[52] S. Harper, D.W. Speicher, in: J.E. Coligan, B.M. Dunn, H.L. Ploegh, D.W. Speicher, P.T. Wingfield (Eds.), Current Protocols in Protein Science, Wiley, New York, 1995 (Unit 10.8).
[53] J. Wen, M. Zhang, T.P. Horan, J.S. Philo, T. Li, J. Wypych, E.A. Mendiaz, K.E. Langley, K.H. Aoki, M. Kuwamoto, Y. Kita, T. Arakawa, Biosci. Biotechnol. Biochem. 65 (2001) 1315-1320.

[54] S.L. Cohen, B.T. Chait, Anal. Biochem. 247 (1997) 257-267.

[55] A.L. Barker, P.R. Unwin, J.W. Gardner, H. Rieley, Electrochem. Commun. 6 (2004) 91-97. 